\title{
Temporary Public Open Space as a Spatial Product on Social Life of City Kampong Community, Jakarta
}

\author{
Siti Sujatini, Tresna P. Soemardi, Abimanyu T. Alamsyah, and Linda D.
}

\begin{abstract}
An increase in population and building density in the capital city of Jakarta has led to an increase in the complexity of the problems if Jakarta. Limited and high prices of land have led to the needs of neglected public open space. Public open space at the Kampong of the city has a temporary function. The temporary public open space as the Third-space is the result of spatial products from the residents' activities. Methods used in this research are literature study and journals review. Data collection used qualitative approach method, i.e. descriptive and empirical assessment on the phenomenon of temporary public open space. The results of the study concluded that the variables of time and community behaviour have some effect on temporary public open space in kampong of the city of Jakarta.
\end{abstract}

Index Terms-Temporary, public open space, community.

\section{INTRODUCTION}

The development of the city and the increase in population of the city of Jakarta has increased the number of space required for urban facilities and infrastructure. The increase in the built area has resulted in the decline of the availability of public open space. Public open space is an open space located on publicly-owned land in the form of park, sporting field, and other open space. This area can be accessed and used by public freely. The city Kampong as a dense residential area of the city has very minimal amount of public open space. As a consequence, the public use street for their activities

\section{LITERATURE REVIEW}

\section{A. Temporary Public Open Space}

Public open space is an open space that can be accessed freely and spontaneously by the public either visually or physically [1]. There are three criteria for essential public space, i.e. Capable of giving meaning or significance to local people individually or in groups (meaningful), responsive to all the wishes of the users and can accommodate all activities in the public space (responsive), capable of accepting the presence of all kinds of people without any discrimination (democratic) all this freedom requires control on spatial functions, traffic circulation and parking of motor vehicles, the placement of street vendors and so on [2].

Temporary public open space is public open space whose function is temporary until the needs of the public space are

Manuscript received May 5, 2014; revised June 30, 2014.

The authors are with University of Persada Indonesia, Indonesia (email: siti_sudjatini1@yahoo.com). met as a result of the development and growth of the city. Haydn in Temporary Urban Space stated that, with the development of the situation and living conditions in urban areas, human needs for space activities grow as well [3].

\section{B. City Kampong}

In the spatial dictionary, City kampong is defined as a housing complex that is part of the city with high population density. This indicates that the housing was built informally, and lack of infrastructure. As a result of the dense condition, health factor has become the main issue.

\section{The Concept of Space}

The concept of place is the origin of the concept of space. Before the concept of space emerged, place was considered as container of all existence on Earth. By making the existence of human beings and all objects on Earth as the basis of the concept of place, place is believed as the container of everything: the world we inhabit is a place, a container that has a limit.

Although place is the place where events occur, this does not mean that space can be detached from time. Space cannot be detached from time. Time is the fourth dimension that accompanies space as part of the three-dimensional existence. Time as a union of dimension unifies the three dimensional space. The concept of space-time is then runs parallel with the concept of movement in space. Space is something that supports the freedom of movement, while place is the stopping place of a movement.

\section{Time and Its Relation with Space}

Space and time are inseparable aspects that were built through a social process. A context that is understood as a place where human activities take place is an effort to organize thing in space and time. If perceived that way, space cannot be thought of as something static, similar to imagining a time without space. Being and time, revealed the meaning of "being" that is defined based on time (temporariness) and is an analysis of the time as the horizon for understanding of the being. This view of philosophy is a phenomenological ontology. Temporariness also discussed as the correlation between time and space. Da-seinwas introduced as the basic of being, an awareness that can understand the being of other things. Looking at spatiality from da-seinpoint of view, analysis of presence and temporariness refers to a limit and aspatio-temporal characteristics. There is a point where this present started, taking place and ends. Spatiality is the presence that might only start a temporality, incapable of deducingspace of time or dissolving it in time entirely. Something presents in space walks in time as psychic events, so that the physics occurs in time not to give a spatial interpretation as a form of 
institutions, but to build something psychical that walks in a time based on factual presence. Temporariness (the aspect of time) functions as the basis of spatiality. Da-sein occurs briefly. Whenever da-sein will exist in a space, it has to determinethe direction and find something like an area or region that can be presented as a place. When something comes with tools, taking care of the thing, or moving around or out of the way, then a region has been found. Temporariness (time) attempted to expose the da-sein into something that was clearly understood in space [4].

\section{E. Theory of Third-Space}

Third-space is an approach on how to see, perceive, and understand a spatial symptom. In addition, it also provides a great opportunity on how the world is described, mapped, and presented. Based on Foucault's approach and an understanding on the essence of space dichotomy, this framework was used to explore every corners of Los Angeles. With a background as a geographer, Soja found previously unimaginable spaces that are called the thirdspace. The idea of the third-space in the urban context, gives more attention on the understanding of a space becoming a place (place making) given by the society. Soja stated that spatiality is the result of a community social relationship that forms social life. This means that space is a product and medium of social life. Being (the existence) can be constructed if it is supported by three aspects, i.e. spatiality(space), historical (time) and sociality. This ontological trialectics should be understood simultaneously to obtain a complete understanding about the reality.

Lefebvre proposed the concept of social space in three categories of space that he called spatial practice or perceived space, and representational space or lived spaces. Originally, spatial practice is a functional space to accommodate the needs of people for space as a place to live. Climate, culture, and behavior factors as basic nature are taken into consideration in creating the spaces, in both residential and neighborhood scale. As people needs grow, space becomes an entity that can be understood without limit. Space not only to meet basic needs (physical), but is also demanded to be able to meet the needs of peopleon hierarchy and social status, as well as being used as a means to show of force. Furthermore, space that covers and dominates spatial practice is what Lefebvre called as representation of space. This is space as imagined by the community (such as architect and urban planner). They regard this as "the true space", and it is used by certain parties to achieve and sustain dominance [5].

\section{METHODOLOGY}

The method of data collection used qualitative approach, i.e. descriptive and empirical study on the phenomenon of the formation of a temporary public open space taking place in the city kampong of Jakarta. The method in this writing is based on theories from literature study on things related to space, social network, and time. Throughliterature study from various sources, observation, interview and Focus Group Discussion were held to find the problems and variables associated with the formation of temporary public open space.

\section{RESUlT AND DisCUSSION}

Researches on Public Space and Behaviour that have been conducted:

1) The idea of the third space in perceiving and understanding spatial symptom (?) classified space into three categories, i.e.

a) The first space as daily space

b) The second space refers to the idea of abstract spatial

c) The third-space as a bridge between the reality of the first space and the imagination of the second space.

The idea of third-space in urban context: the understanding of a becoming a place (place making) given by the society. Space is the result of a community social relationship that forms social life, space as a product and medium of social life.

2) Space can play various roles in socio-economic world:

a) Space can take the roles from a production power (others are more traditional power such as factory, tools and machinery)

b) Space itself can be a commodity that is consumed productively (e.g. the land where the factory was constructed).

c) Space is important politically in facilitating the system control.

d) Space supports property reproduction and relation (e.g. expensive community for the capitalist and slums for the poor )

e) Space can be in the form of superstructure that looks neutral but concealing economic base that produces superstructure which is far from being neutral.

3) The presence of unity of space - time - actors:

a) Space as a spatial element that accommodates activities. The supporting elements are the ones having a role in in changing the layout/ arrangement/composition of a space so that the space possesses having various shapes and different atmosphere.

b) Time dynamic is how the role of time that seems arranging, controlling and even deciding when an activity should be held. Daily, weekly, monthly or annual activities will be different depending on society.

c) Actor as an aspect that plays an important role in understanding a space becoming a place is also an important element in the formation of an activity.

There are three paradoxes found in the practice of the use of public space: paradox between informality and formality, paradox between public and private space and, paradox between the phenomenon of regularity (the order) and disorder (chaos) in the process of human mental movement to familiarize with territory, conditions and situation that is taking place

4) High population and housing density significantly influence human ability to adapt to the environment, so that within certain limitation, the conditions are influential in reaching optimization of his life. Factors influencing the ability of people to adapt to 
the environment are:

a) Family territorial area (land and building area)

b) The existence of spatial functions in every building that can accommodate basic necessities of space

c) Public facilities in the form of an open space place where people can play. Place or space where people can interact with each other.

d) Courtyard of a house and the width of the road in front of the house as a substitute for an open space and can serve as a place to interact

5) Observations on some city kampong in Jakarta show that public open space for people to interact is difficult to find due to limited land. To meet the needs on public space, the utilization of public open space is expanded temporarily to several areas, as shown in Fig. 1 - Fig. 3, below [6]

a) Main roads, used as area for playing, trade and social interactions, and car park area

b) Road or small alleys as children playground, trading area, area for social activities and interaction, motor parking area, household service are, etc.

c) The field within the kampong is used not only for sports, but also for interaction among the residents, trading place, and children playground.

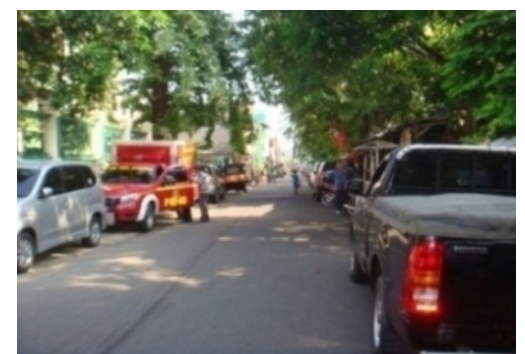

Fig. 1. Space on the main road during Night-time and holiday used for car parking area.

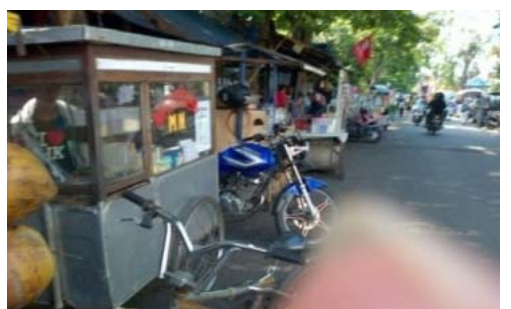

Fig. 2. Space on the main road during morning-time and holiday used forVendor parking area.

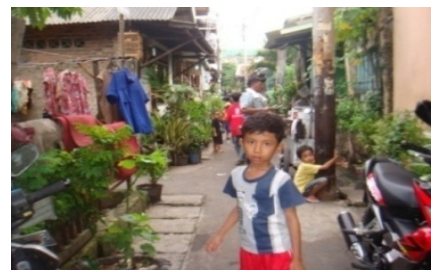

Fig. 3. Space on the small street/alley isused for children's play and interactionarea, another day is used traffic.

In the phenomenon of this temporary public open space there is a correlation between space and time or a space that is formed in conducting daily activities related to public open space. Social interaction activities in open spaces invites interaction and activity, temporarily, and when the time duration in end the space will return to its original function. Activities can bring the place with different meanings and bring community closer. With social network stimulation and the diversity of individual experiences, different urban activities can be created, as shown in Table I, below [7].

TABLE I: The Activity Pattern of Public Open Space in Some CITY KAMPONG OF JAKARTA

\begin{tabular}{|c|c|c|}
\hline $\begin{array}{l}\text { Types of public } \\
\text { open space }\end{array}$ & $\begin{array}{l}\text { identification of } \\
\text { public open } \\
\text { spaces }\end{array}$ & $\begin{array}{l}\text { The description of } \\
\text { identification }\end{array}$ \\
\hline Alley & $\begin{array}{l}\text { Time of usage } \\
\text { Activity that is } \\
\text { taking place }\end{array}$ & $\begin{array}{l}\text { Daily, certain time } \\
\text { pedestrian/ motorcycle, } \\
\text { bicycle traffic, socialization } \\
\text { among neighbours, trading, } \\
\text { children playground } \\
\text { Residents and public } \\
\text { Road width } 0.80 \mathrm{~m}-2.00 \mathrm{~m} \text {, } \\
\text { pedestrian, mostly without } \\
\text { canopy, there are only green } \\
\text { plants, mostly used for } \\
\text { motorcycle parking, place to } \\
\text { sit , place to sell, and place } \\
\text { to dry clothe }\end{array}$ \\
\hline Sport field & $\begin{array}{l}\text { Time of usage } \\
\text { Activity that is } \\
\text { taking place } \\
\text { Users } \\
\text { Quality of Public } \\
\text { open space }\end{array}$ & $\begin{array}{l}\text { Daily } \\
\text { Sport, interaction and selling } \\
\text { area for residents, etc } \\
\text { Residents, Vendors } \\
\text { Total area of the field } 15.00 \\
m \text { X } 15.00 \mathrm{~m} \text {, pavement, } \\
\text { without plants }\end{array}$ \\
\hline The main road & $\begin{array}{l}\text { Time of usage } \\
\text { Activity that take } \\
\text { place } \\
\text { Users } \\
\text { Quality of Public } \\
\text { open space }\end{array}$ & $\begin{array}{l}\text { Daily, weekend, certain time } \\
\text { Interactions between area } \\
\text { residents, car parking area } \\
\text { residents } \\
\text { Residents, Public } \\
\text { Wide of street } 15.00 \mathrm{~m} \\
\text { A few tree, some sitting, } \\
\text { some damage road }\end{array}$ \\
\hline
\end{tabular}

\section{CONCLUSION}

Theoretical assessment, journal review and field observationconcluded that public open space in the city kampong is more temporary in its usage. The temporary public open space exists and produces social networking patterns of interactions between a actorsand the formation of spatial configuration with temporary functions. Temporary public open spaces can also be referred to as third-space. The result of the study concluded that the variables of time and behaviour of society with different cultural characteristics have some effects on the formation of temporary public open space in the city of Jakarta.

All temporary places are usually illegal and should be regulated with a perm it of an event and planner's regulation. Temporality can produce different social interactions within the time restrictions compared to the usual pattern of architecture and planning. A small, temporary event can have a huge impact. Therefore, the function of temporary public open space should be managed to avoid a bigger negative impact. Community participation is expected to optimize the utilization of public open space in the kampong area. Public participation should certainly be supported by government regulation and license.

\section{REFERENCES}

[1] M. Carmona, H. Tim, O. Taner, and T. Steve, Public Places, Urban Space, the Dimension of Urban Design, Oxford: Architectural Press, 2006, pp. 112-115. 
[2] S. Carr, F. Mark, G. R. Leanne, and M. S. Andrew, The Value, and Nature of Public Space, Public Space Evolving, New York: Cambridge University Press, 1992, pp. 34-39.

[3] F. Hayden et al., Temporary Urban Space: Concept for the Use of Spaces, Berlin: Birkhauser, 2006, pp. 72-76.

[4] M. Heidgger, Conceptializing of Being and Tim, and Place Making, Britain: The Camelot Press, 1985.

[5] E. W. Soja, Temporary Public Open Space as Third-Space, UK: Blackwell Cambridge, pp. 70-82, 1996.

[6] Observations of Public Open Space on Some Kampong of City in Jakarta, 2013

[7] The Activity Pattern of Public Open Space on Some Kampong of City in Jakarta, 2013.

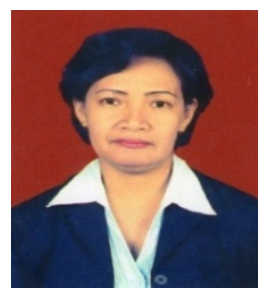

Siti Sujatini was born in Solo, Indonesia, in 1963. She received her bachelor degree from the Department of Architecture, Faculty of Engineering, and University of Diponegoro in 1996, and master degree in environmental science from the University of Indonesia, in 2006. Since 2011 she has been a doctoral student at the University of Indonesia.

She has published her researches on several journals and proceedings. She is an active researcher, has received some funding from the Directorate General of Higher Education (DIKTI) since 2012.

Ir. Siti Sujatini Msi is the head of architecture Dept., Faculty of Engineering University of Persada Indonesia, Indonesia

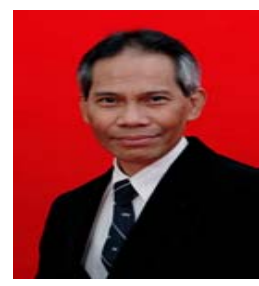

Tresna P. Soemardi was born in Palembang, in 1955. He was promoted to professor in March 2005. He received his bachelor degree in mechanical engineering, Faculty of Industrial Technology, and Institute of Technology Bandung. He revised his bachelor degree in econ., from the Faculty of Economic University of Indonesia in 1996. He received his master and degrre in environmental science from University of Indonesia, and Doctoral degree aplied mechanics \& advanced materials, from the Ecole central de Paris-France.

$\mathrm{He}$ is a professor in mechanics product innovation, design, prototyping and develop. At the University of Indonesia, Indonesia.

Prof. Dr. Ir. Tresna Priyana Soemardi, SE, Msi has been a lecturer in the Department of Machine, Faculty of Engineering, University of Indonesia, Indonsia since 1983

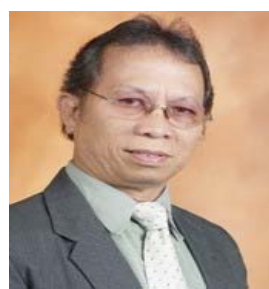

Abimanyu T. Alamsyah was born in Yogyakarta, in 1946. He was graduated in architecture, Faculty Engineering University of Indonesia in 1975 and he had opportunity to study diploma in development planning (Dip DP), Develop. Planning Unit, School for Environmental Studies, University College London, UK. He earned his master of science (in major - Regional and Rural Develop.), IPB, Bogor, Indonesia. He earned his doctorate degree in faculty of Environmental Science UI, in 2006.

Abimanyu Takdir Alamsyah is lecturer of the Department of Architecture Faculty of Engineering, University of Indonesia. He was honored as a professor in 2009. He specializes in coastal architecture. His teachings are mostly related to housing and architecture on building and environment develop. etc.

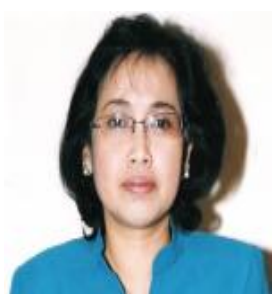

Linda Darmajanti was born in Medan, in 1954, Indonesia. She graduated in sociology from UI and gained her received his master degree in Urban Planning from Technology Institute of Bandung (ITB) in 1993. Her doctoral degree was achieved in 2002 from University of Indonesia, majoring in Social Capital.

She is involved in many kinds of researches like Research Team and Project Officer for CSR Master Plan P.T. Indah Tambangraya Megah and Research Team for Mine-closure Plan Project, from social, economic and cultural aspect P.T. Indah TambangrayaMegah.

Linda Darmajanti is a full time lecturer in Depart. of Sociology, University of Indonesia. Her specifications of teaching are urban sociology, urban and regional development planning, community develop./CSR, social planning, and social capital. 